\title{
Boosting land restoration success in the Great Green Wall through the use of symbiotic microorganisms for propagated tree seedlings
}

\author{
Barkissa FOFANA ${ }^{1,3^{*}}$, Moctar SACANDE ${ }^{2}$, Fanta BLAGNA ${ }^{1,3}$, Théophile O. DIBLONI ${ }^{3}$, \\ Emmanuel COMPAORE ${ }^{4}$, Kadidia B. SANON ${ }^{3}$, Ynoussa MAIGA ${ }^{1}$ and \\ Aboubakar S. OUATTARA ${ }^{1}$ \\ ${ }^{1}$ Université Joseph KI-ZERBO BP : 7021 Ouagadougou 03, Burkina Faso. \\ ${ }^{2}$ Forestry Department, FAO Rome Italy, BP: 00153 Rome. \\ ${ }^{3}$ Département Environnement et Forêt, INERA BP : 7047 Ouagadougou 03, Burkina Faso. \\ ${ }^{4}$ Département Gestion des Ressources Naturelles et Systèmes de Production, INERA, BP : 7047 Ouagadougou \\ 03, Burkina Faso. \\ *Corresponding author; E-mail: barkissafofana@gmail.com
}

\begin{abstract}
Several studies have clearly demonstrated the scientific and practical use of the symbiotics microorganisms for plants in earth ecosystems. The main goal of this study was to rehabilitate a degraded soil of the sahelian zone of Burkina Faso by using the rhizobia and mycorrhizal symbiosis through the inoculation technique. Native rhizobial strains were isolated from soil samples. These strains were then tested in laboratory and greenhouse conditions for their effects on the nodulation and growth of Vachellia seyal. At the end of these tests three promising strains were selected to form a complex that was used with or without arbuscular mycorrhizal fungus for the inoculation of plants produced in nursery or issued from direct seedling at the field. After 3,12 and 14 months of cultivation, respectively, the growth parameters of plants such as the height and the collar diameter were measured. In addition, the field survival rate of plantations was evaluated. The results showed that inoculation has improved the growth and survival rate of Vachellia seyal plants in the field. The double inoculation was more effective than the single inoculation. With these promising results, we recommend inoculation of seedlings for a better success of restoration plantings in the Sahel.
\end{abstract}

(C) 2020 International Formulae Group. All rights reserved.

Keywords: Symbiosis, native strains, rehabilitate, inoculation, sahelian zone.

\section{INTRODUCTION}

Several studies have pointed out the fact that, due to climate change and anthropic pressure, the rate of depletion of plant cover is much higher than that of its regeneration (Ozer and Ozer, 2005; FAO, 2016). Severe and frequent droughts, as well as floods, contribute to the destruction of natural ecosystems (FAO, 2016). As a result of its fragile economy, Africa is considered to be the most vulnerable region to the effects of climate change (FAO-CILSS, 2008). Indeed, many studies have shown a reduction in the vegetation cover in the Sahel region of Africa (Amogu, 2009).

During the last few years, the Sahelian population growth rate has increased significantly and this has contributed to 
substantial environmental changes. This anthropic pressure has triggered a significant deforestation for energy, lumber and agricultural purposes. In addition, the expansion of livestock generates an overgrazing, preventing the regeneration of some shoots. All of this contributes to the degradation of the vegetation cover (Ozer and Ozer, 2005). As a result, the soil is exposed to water erosion, wind erosion, etc., inducing significant perturbations of its physical, chemical and biological properties (Requena et al., 2001; Duponnois et al., 2017). This can be aggravated by the development of desertlike areas that can spread and merge (Nahel, 2004). The absence of actions to prevent this phenomenon can lead to many problems such as food insecurity, poverty, environmental migration, etc. (Safriel et al., 2005).

As a result, many development programs have engaged to combat this phenomenon. Being considered as a problem of local development, the fight against desertification requires local solutions (Requier-Desjardins and Caron, 2005). The Africa's Great Green Wall initiative is one of such restoration and rural development programs (AUC/PA-GGW, 2012). It was launched since 2007 to combat the effects of climatic change and desertification and develop sustainable development pathways in this food-insecure region and its highly vulnerable populations and ecosystems. Led by the African Union, the initiative aimed at achieving a transformational change for millions of people by increasing resilience in the Sahara and the Sahel through an integrated landscape approach (Sacande and Berrahmouni, 2016; Sacande and Berrahmouni, 2018).

In Burkina Faso, battle against desertification have begun since the 1960s with various stakeholders involved to test or recommend mitigation techniques (Hien et al., 2004) including mechanical ("zaï", "half moons", etc), biological (the straw), farming (manure, compost) and agroforestry techniques (reforestation, assisted natural regeneration, grass mat, etc.). Globally, the application of these techniques has gained a positive effect on the fight against desertification. However, all of them have limitations (Roose et al., 2017). Indeed, the large scale application of biological and farming techniques can be limited by the availability of the material used. For agroforestry techniques, the lack of water during the dry season is an obstacle to their success (Roose et al., 2017). Thus, the optimization of these techniques could be beneficial in the context of an effective and sustainable fight against desertification. In addition to their environmental and ecological interest, trees are important sources of income, food security and traditional pharmacopoeia for rural populations (Bonkoungou, 2004). Therefore, the optimization of an agroforestry and agroecology technique such as land restoration and reforestation will be interest in the context of an integrated fight against desertification. Specifically, reforestation with permanent legumes could be appropriate.

Among these legumes, acacias from the arid and semi-arid regions of tropical and subtropical areas such as Acacia seyal, (known as Vachellia seyal), Acacia senegal (known as Senegalia senegal) etc. are pioneers for the reforestation of dry soils, with low fertility (Räsänen, 2002). The faculty of these legumes to grow in these conditions is related to its ability to develop a symbiotic association with arbuscular mycorrhizal fungi (AMF) and bacteria of the group of rhizobia which are atmospheric nitrogen-fixing bacteria (Graham and Vance, 2003; da Silva et al., 2014).

Several studies have clearly demonstrated the scientific and practical use of this symbiosis for plants, whether in the natural or man-made ecosystems (Fortin et al., 2008). Indeed, it has been shown that AMF allow the mobilization of water and minerals (especially phosphorus) beneficial for plants (Lambers et al., 2008). In addition, the symbiotic nitrogen-fixing bacteria convert the atmospheric nitrogen $\left(\mathrm{N}_{2}\right)$ into mineral forms $\left(\mathrm{NH}_{3}\right)$ that can be assimilated by the plants (Matiru and Dakora, 2004). These abilities can be used to recover degraded lands, as it is 
not only a cheap technology, but also, an environmentally friendly. In order to increase the chances of success of such a technique, degraded soils, which are poor in symbiotic microorganisms, must be supplemented with nitrogen fixing bacteria. However, phosphorus deficiencies in tropical soils can limit the establishment of the nitrogen-fixing symbiosis. Hence, AMF, known for their ability to improve phosphate nutrition of plants, could be used in association with nitrogen-fixing bacteria to provide the phosphorus necessary for their symbiosis with plants (Temegne et al., 2017). The inoculation technique is not commonly used although it would be a great added value and a natural boost to the success of large scale restoration program such as the Africa's Great Green Wall. To our knowledge this is the first work of this type at scale in the field in Burkina Faso and even in the whole GGW restoration program.

The objective of this study is to increase success of restoration and rehabilitation of a degraded soils area of the sahelian region of Burkina Faso as part of the Great Green Wall, by using rhizobial and mycorrhizal symbiosis through inoculation technique. Vachellia seyal (Del) has been chosen as a model native species because it is planted a lot for its multi-purpose uses including its production of commercial gums.

\section{MATERIALS AND METHODS \\ Plant material}

The seeds of Vachellia seyal and Senegalia senegal provided by the "Centre National de Semences Forestières (CNSF)" of Burkina Faso, were used.

\section{Microbial material}

Rhizobial strains isolated from soil in the sahelian zone of Burkina Faso were used as native strains and rhizobial strains ORS 3574, 3588 and 3607 (isolated from Senegalia senegal nodules) provided by the "Laboratoire Commun de Microbiologie de Dakar" were used as reference strains.

A strain of Rizophagus irregularis (Ri) was used as a mycorrhizal inoculant. The strain was developed using a corn culture for 6 months on a sand. This inoculant consisted of fragments of mycorrhizal roots and spores.

\section{Soil material}

The soil used for the Rizophagus irregularis strain development was issued from Dori. For the production of plants in greenhouse a sandy soil used provide of Kaya. The nursery substrate used for plants production in nursery provide of Ouagadougou. The principal characteristics of these soils are presented on Table 1.

\section{Mycorrhizal status of Vachellia seyal with the strain of AMF}

The mycorrhizal status of Vachellia seyal associated to Rizophagus irregularis inoculant used was evaluated as follow :

Vachellia seyal seeds were planted in 10 plastics pots of $1.5 \mathrm{~L}$ containing $2 \mathrm{~kg}$ of a sterile sandy soil. The pots were inoculated with $10 \mathrm{~g}$ of Rizophagus irregularis inoculant. After 3 months in greenhouse, the fine roots were collected for the assessment of mycorrhization according to the method of Trouvelot et al., 1986.

\section{Isolation of indigenous rhizobial strains}

The indigenous or native rhizobial strains were isolated from host plants nodules grown in laboratory conditions as described below.

\section{Soil sampling}

Soil samples were collected in the locality of Bani $\left(14^{\circ} 0.3936^{\prime}: \mathrm{N}, 1^{\circ} 42.4686^{\prime}\right.$ : $\mathrm{W}, 311 \mathrm{~m} \mathrm{~A}$ ) located about $15 \mathrm{~km}$ from Djibo, in the Soum province. The soil was mined to a depth of $30 \mathrm{~cm}$ in the rhizosphere of legumes tree in October 2016. Totally, ten (10) samples were collected. These samples were passed a 2-mm sieve, respectively. They were then mixed to get a balanced composite sample for the host plants growth.

\section{Host plants cultivation}

The composite soil sample was used for the cultivation of two legumes, Senegalia senegal and Vachellia seyal as host plants in 
Gibson tubes (Gibson, 1980). The seeds of these plants were scarified with sulfuric acid $96{ }^{\circ}$ and pre-germinated in Petri dishes containing $8 \%$ agar medium (w/v) at $28{ }^{\circ} \mathrm{C}$ for 72 hours. The plants were transplanted into Gibson tubes containing a sterile Jensen nitrogen-free medium (Vincent, 1970), and then incubated under wet atmospheric conditions for 48 hours. For each plant species, 5 repetitions were performed. The test was conducted in the laboratory at ambient temperature, with intermittent lighting (16 hours on day time and 8 hours at night). After four (4) days of growth, the young plants were then inoculated with $1 \mathrm{ml}$ of the composite soil sample suspension ( $10 \mathrm{~g}$ of soil in $90 \mathrm{ml}$ of physiological water). After two (2) months of growth, the nodules on the roots were collected.

\section{Isolation of rhizobia from the nodules}

The isolation of rhizobia was carried out in sterile conditions according to the technique of Weaver and Frederick (1982). Each individual colony obtained was purified by successive streaks on Yeast-ExtractMannitol-Agar (YEMA) medium (Vincent, 1970). A total of about thirty isolates were obtained.

\section{Infectivity test}

The isolates obtained from the plants nodules can only belong to the rhizobia if they are able to renodulate these plants. For this, the infectivity (ability to form nodules on the host plant) of the isolated strains were tested. So, the plants seeds were pre-germinated and cultivated on the Jensen medium in Gibson tubes (Vincent, 1970) and then, inoculated with the different isolates $(1 \mathrm{ml}$ of bacterial culture per plant); 3 replications were made by isolate. The nodulation was followed, and the first twelve infectious strains were used to be tested in the greenhouse.

\section{Selection of efficient strains}

Scarification and surface sterilization of Vachellia seyal seeds were achieved by soaking in sulfuric acid ( $96^{\circ}$ for $10 \mathrm{~min}$ ). Then, they were cultivated in $1.5 \mathrm{~L}$ containers containing $2 \mathrm{~kg}$ of sterilized sand (at $121{ }^{\circ} \mathrm{C}$ for 1 hour). After two weeks of cultivation, the young plants were inoculated with the native rhizobia isolates. Ten replications were performed per strain. Each plant was inoculated with $1 \mathrm{ml}$ of bacterial culture $\left(10^{9}\right.$ bacteria per $\mathrm{ml}$ ). The test was conducted in a greenhouse at surrounding temperature. The experimental device was a totaly randomized.

After 2 months of cultivation in the greenhouse, the number of nodules was counted and the collar diameter, plant height and the biomasses (shoot and root) were evaluated. At the end of this experiment, 3 strains were selected to form the complex of native rhizobia used for field test.

\section{Field experimental tests \\ Study site}

The study area was a degraded land located in Som $\left(14^{\circ} 3.5412 \mathrm{~N}, 1^{\circ} 44.0460 \mathrm{~W}\right.$, $297 \mathrm{~m} \mathrm{~A}$ ), a village in the Soum province, at about $10 \mathrm{~km}$ from Djibo, in the Sahelian region of Burkina Faso. The rainfall distribution during the two years experiment period is reported in Table 2 .

\section{Preparation of the field}

The experiment field (4.5 ha: 225/200 m) was plowed by the Delphino plow and then to set up the test. The field was divided into two parts of 2.25 ha $(225 / 100 \mathrm{~m})$. Each part has been delimited in microplots of 0,125 ha $(50 \mathrm{~m} / 25 \mathrm{~m})$.

Soil samples were collected before the tests were put in place and their physicochemical characteristics determined for an indication of the overall state (Table 3).

\section{Experimental design}

The experimental design consisted of 2 blocks with two factors: direct seedlings and plantations. In each block, completely randomized a total of six (6) treatments were carried out triplicate and each replication was put on a parcel unit. The different treatments were as follow:

- Vachellia seyal + native rhizobial strains complex: (RB); 
- Vachellia seyal + reference rhizobial strains complex: (RS);

- Vachellia seyal + the arbuscular mycorrhizal fungus: (CMA);

- Vachellia seyal + native rhizobial strains complex + arbuscular mycorrhizal fungus: $(\mathrm{CMA}+\mathrm{RB})$;

- Vachellia seyal + reference rhizobial strains complex + arbuscular mycorrhizal fungus: (CMA +RS);

- Vachellia seyal control: (T)

\section{Direct sowing}

Field sowing was carried out in August 2017 with scarified seeds of Vachellia seyal. The inoculation with the rhizobia was carried out by coating the seeds as follow: the seeds were immersed into a mixture of bacteria $\left(10^{9}\right.$ cells/ml) and a sugar (80\%: w/v) solution (3/4; 1/4). The inoculation with the arbuscular mycorrhizal fungus was performed with $5 \mathrm{~g}$ of mycorrhizal inoculant per seed pocket. The seeding was carried out on lines (7 lines/microplot) made up of "half-moons" at the rate of 3 pockets per "half-moon". After that, measurements (collar diameter and height) were performed on the plants at 3,12 and 14 months of seeding. For each treatement a total of fifteen plants were measured.

\section{Plantation}

In order to perform the plantation, two steps were considered: the production of plants in nursery and the field plantation.

\section{Production of plants in nursery}

Vachellia plants were produced in nursery in May 2017. The crop substrate (non- sterile) was mixed $(1 / 3, v / v)$ with a sandy soil $(2 / 3, v / v)$. Vachellia seyal seeds were pregerminated and sown in plastic pots of 1,5 1 containing $2 \mathrm{~kg}$ of soil. The inoculation with the arbuscular mycorrhizal fungus was carried out at the time of seeding at a rate of $10 \mathrm{~g}$ per pot. The inoculation with the rhizobial strains complexes was carried out after two weeks of culture, with $1 \mathrm{ml}$ of rhizobium culture $\left(10^{9}\right.$ bacteria/ml) per pot. Three replications of fifty plants were carried out by treatment. After 3 months of culture, the growth parameters were measured. A total of thirty plants were measured for each treatment.

\section{Plantation in field}

After three months of culture the plants were transplanted to the field in August 2017 according to the above experimental procedure. For each treatment, a parcel unit was used per replication. The plantations were carried out on lines (7 lines/microplot).

3, 12 and 14 months after transplanting the growth parameters (collar diameter and height) were measured for at about thirty plants per treatment. In addition, the survival rate was evaluated at14 months following equation : $\mathrm{SR}=\frac{R P}{P P} \times 100$

With $\mathrm{SR}=$ Survival rate; $\mathrm{RP}=$ number of plants surviving at the period $t$ and $\mathrm{PP}=$ number of planted feet.

\section{Statistical analysis}

The data collected were analyzed with software R-3.5.1, 2018; variance analyses were performed and averages were compared with the Newman Kheuls' test at the probability $\mathrm{p} \leq 0.05$.

Table 1: Physicochemical characteristics of the soils that were used.

\begin{tabular}{llll}
\hline Characteristics physicochemical & Inoculum soil & nursery substrate & Sandy soil \\
Clays (\%) & 3.92 & 11.76 & 5.88 \\
Silt (\%) & 1.96 & 15.69 & 1.96 \\
Sand (\%) & 94.12 & 72.55 & 92.16 \\
pHwater & 5.89 & 7.78 & 6.08 \\
O.M (\%) & 0.276 & 1.522 & 0.391 \\
Total C (\%) & 0.160 & 0.883 & 0.227
\end{tabular}




\begin{tabular}{llll} 
Total N (\%) & 0.012 & 0.076 & 0.018 \\
$\mathbf{C} / \mathbf{N}$ & 13 & 12 & 13 \\
Total P (ppm) & 126 & 691 & 314 \\
P.ass (ppm) & 6.03 & 3.13 & 2.9 \\
Total K & 661 & 813 & 559 \\
$\mathbf{K} . \mathbf{d i s p o}$ & 36.04 & 35.06 & 29.22 \\
$\mathbf{C a}^{2+}\left(\mathbf{m}^{2} / \mathbf{1 0 0} \mathbf{g}\right)$ & 1.36 & 1.46 & 1.89 \\
$\mathbf{M g}^{\mathbf{2 +}}\left(\mathbf{m}^{2} / \mathbf{1 0 0} \mathbf{g}\right)$ & 1.62 & 0.63 & 1.43 \\
$\mathbf{K}^{+}\left(\mathbf{m}^{2} / \mathbf{1 0 0} \mathbf{g}\right)$ & 0.11 & 0.07 & 0.11 \\
$\mathbf{N a}^{+}\left(\mathbf{m}^{2} / \mathbf{1 0 0} \mathbf{g}\right)$ & 0.02 & 0.02 & 0.02 \\
\hline
\end{tabular}

OM: organic matter, $\mathrm{C}$ : carbon, $\mathrm{N}$ : nitrogen, $\mathrm{K}$ : potassium, $\mathrm{K}$ dispo: potassium available, P: phosphorus, P.ass: assimilable phosphorus.

Table 2: Average rainfall of the study area during two years of experiment.

\begin{tabular}{|c|c|c|c|c|c|c|c|c|c|c|c|c|}
\hline 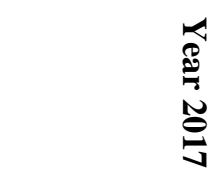 & 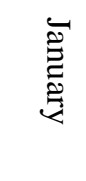 & 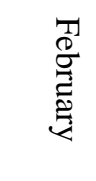 & $\begin{array}{l}3 \\
\stackrel{3}{0} \\
\stackrel{3}{3}\end{array}$ & 疍 & $\underset{2}{3}$ & $\breve{\Xi}$ & 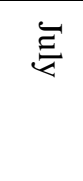 & 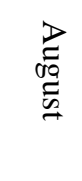 & 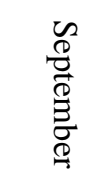 & $\begin{array}{l}0 \\
\stackrel{\circ}{+} \\
\stackrel{0}{0} \\
\stackrel{\oplus}{9}\end{array}$ & 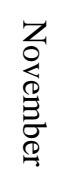 & 0 \\
\hline Rainfall (mm) & 0 & 0 & 0 & 0 & 71.2 & 105.2 & 98.3 & 84.7 & 114.7 & 11.5 & 0 & 0 \\
\hline 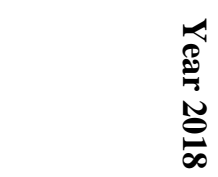 & 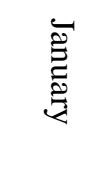 & 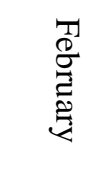 & $\begin{array}{l}3 \\
\text { مै } \\
\stackrel{2}{6}\end{array}$ & 蛋 & $\underset{2}{3}$ & $\overleftrightarrow{\Xi}$ & $\bar{\Xi}$ & 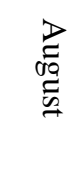 & 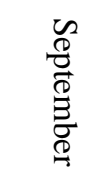 & $\begin{array}{l}0 \\
0 \\
\stackrel{0}{0} \\
\stackrel{0}{\oplus} \\
\stackrel{9}{9}\end{array}$ & 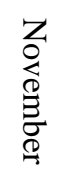 & $\begin{array}{l}8 \\
\varnothing \\
\varnothing \\
\varnothing \\
8\end{array}$ \\
\hline Rainfall (mm) & 0 & 0 & 0 & 0 & 30.6 & 83.60 & 127 & 216 & 132 & 24.2 & 0 & 0 \\
\hline
\end{tabular}

Table 3 : Soil physicochemical characteristics of experiment field.

\begin{tabular}{|c|c|c|}
\hline Characteristics physicochemical & Plantation field soil & Seedling field soil \\
\hline Clays (\%) & 15.69 & 15.69 \\
\hline Silt (\%) & 17.64 & 19.6 \\
\hline Sand (\%) & 66.67 & 64.71 \\
\hline pHwater & 5.22 & 6.72 \\
\hline OM (\%) & 1.219 & 0.943 \\
\hline Total C (\%) & 0.707 & 0.547 \\
\hline Total N (\%) & 0.053 & 0.058 \\
\hline $\mathrm{C} / \mathrm{N}$ & 13 & 9 \\
\hline Total P (ppm) & 377 & 377 \\
\hline P.ass (ppm) & 1.69 & 1.56 \\
\hline Total K & 966 & 915 \\
\hline K. dispo & 39.93 & 23.45 \\
\hline $\mathrm{Ca}^{2+}\left(\mathrm{m}^{2} / 100 \mathrm{~g}\right)$ & 1.42 & 1.69 \\
\hline $\mathrm{Mg}^{2+}\left(\mathrm{m}^{2} / 100 \mathrm{~g}\right)$ & 0.42 & 0.82 \\
\hline $\mathrm{K}^{+}\left(\mathbf{m}^{2} / 100 \mathrm{~g}\right)$ & 0.17 & 0.07 \\
\hline $\mathrm{Na}^{+}\left(\mathrm{m}^{2} / 100 \mathrm{~g}\right)$ & 0.02 & 0.02 \\
\hline
\end{tabular}




\section{RESULTS}

\section{The mycorrhization test}

The mycorrhization parameters observed were the mycorrhization frequency (F) and the intensity of mycorrhization (I). Our mycorrhization test revealed $100 \%$ for the frequency and $63.19 \%$ for the intensity.

\section{Greenhouse tests for the selection of rhizobial strains}

The results of statistical comparison of the effects of inoculation with rhizobia on the growth parameters under greenhouse conditions are summarized in Table 4. After 2 months of plants growth in the greenhouse, a significant difference was noticed between the inoculated and the non-inoculated plants (control) when the collar diameter was considered. However, there was no significant difference between the effects of the different strains of rhizobia on the collar diameter when the inoculated plants were compared with each other.

When the height was considered, only the inoculation with the strain AYJ2 showed a significant positive effect compared to the non-inoculated control. The difference with the other isolates was not significant compared to the control.

For the nodulation, all of the rhizobial strains induced the formation of nodules in the plants root, while the control was not nodulated. The AYJ5 strain induced a positive significant effect of nodulation compared to the strains AYJ1, AYJ4, AGJ1 and AGJ3.

Regarding the shoot biomass, only the inoculation with strains AYJ2 and AYJ3 resulted in positive significant difference compared to the non-inoculated plants. It also emerged that their effects on shoot biomass were significantly higher than those of strains AYJ4 and AGJ6. For the other isolates, the observed difference was not significant.

For root biomass, all of the rhizobia tested produced a significant effect compared to the control excepted AYJ1 and AGJ6. The highest values were obtained with strains AYJ3 (182.6 mg) followed by AGJ4 (169.5 $\mathrm{mg})$ and AYJ2 (152.6 mg).

\section{Field experimental tests Direct sowing}

In general, the inoculation stimulated the growth of plants from direct sowing in the field (Figure 1). Regarding collar diameter, at 3 months after seeding, the single inoculation (CMA, RB and RS) had showed a significant effect compared to the non-inoculated control (T). Dual inoculation (CMA+RB and CMA+RS) favored a better development of the collar diameter compared to the single inoculation (CMA, RB and RS) and the control (T), respectively. In dual inoculation the native rhizobial strains $(\mathrm{CMA}+\mathrm{RB})$ was more effective than that of the reference ones $\mathrm{CMA}+\mathrm{RS}$ ).

For plant height, the double inoculation (CMA+RB and CMA+RS) significantly stimulated this parameter compared to the single inoculation (CMA, RB and RS). In the same way as the collar diameter, there was a significant difference between in dual inoculation with the native rhizobial strains $(\mathrm{CMA}+\mathrm{RB})$ and the reference ones (CMA+RS). However, no significant difference was observed between the single inoculation (CMA, RB and RS) and the control (T).

At 12 months, the collar diameter with the double inoculation $(\mathrm{CMA}+\mathrm{RB}$ and CMA+RS) was significantly higher than the single inoculation one (CMA, RB and RS). The difference between double inoculation with the native rhizobial strains $(\mathrm{CMA}+\mathrm{RB})$ and the reference ones (CMA+RS) was also significant. There was a significant difference with the single inoculation (CMA, RB and RS) compared to the non-inoculated control (T). The inoculation with the rhizobial strains (RB and RS) showed a significant effect compared to the one with the arbuscular mycorrhizal fungus (CMA).

Regarding growth height, a nonsignificant difference was observed between the dual inoculation (CMA+ RB and $\mathrm{CMA}+\mathrm{RS}$ ) and the single inoculation with the rhizobial strains (RB and RS) ; however, this difference is significant when compared to the arbuscular mycorrhizal fungus (CMA) inoculation alone which had lower growth. 
There was no significant difference between the native rhizobial strains (RB) and the reference ones (RS). Globally, the study showed a significant difference between the simple inoculation (CMA, RB and RS) and the non-inoculated control $(\mathrm{T})$.

At 14 months, the collar diameter with the double inoculation (CMA+ RB and CMA+RS) was significantly superior with the single one (CMA, RB and RS). The effect produced was more significant with the native rhizobial strains (CMA+ RB) compared to the reference ones $(\mathrm{CMA}+\mathrm{RS})$. There was a significant difference between the single inoculation (CMA, RB and RS) compared to the non-inoculated control $(\mathrm{T})$. The inoculation with the rhizobial strains (RB and RS) showed a significant effect compared to the arbuscular mycorrhizal fungus one (CMA).

As per the height, the difference was significant with the double inoculation $(\mathrm{CMA}+\mathrm{RB}$ and $\mathrm{CMA}+\mathrm{RS})$ compared to the single inoculation (CMA, RB and RS). There was also a significant difference in the single inoculation (CMA, RB and RS) compared to the non-inoculated control $(\mathrm{T})$. The inoculation with the rhizobial strains (RB and RS) had a significant effect compared to the arbuscular mycorrhizal fungus one (CMA).

\section{Plantation}

\section{Collar diameter and height}

In general, the inoculation stimulated the growth of the plants (Figure 2). At 3 months in nursery, concerning the collar diameter, the inoculation induced a significant effect on the inoculated plants compared to those not inoculated. There was a significant difference between the native rhizobial strains (RB) compared to that of reference rhizobial one (RS) with single as double inoculation. Also, a significant effect of inoculation was noticed with the native rhizobial strains (RB) compared to the mycorrhizal arbuscular fungi (CMA).

For the height, only the double inoculation with the complex of native rhizobial strains $(\mathrm{CMA}+\mathrm{RB})$ which showed a significant effect compared to the single inoculation (CMA, RB and RS). The inoculated plants have evolved significantly compared to the non-inoculated controls (T).

3 months after planting, the growth in the collar diameter was better in the inoculated plants than in the control. The double inoculation $(\mathrm{CMA}+\mathrm{RB}$ and $\mathrm{CMA}+\mathrm{RS})$ was more effective than the single one (CMA, $\mathrm{RB}$ and RS).

No significant difference was registered in height.

12 months after planting, the inoculation induced a better development on the collar diameter of the inoculated plants compared to that of those not inoculated. The double inoculation (CMA+RB and CMA+RS) revealed a significant effect compared to the single inoculation (CMA, RB and RS).

Regarding the height, the double inoculation $(\mathrm{CMA}+\mathrm{RB}$ and $\mathrm{CMA}+\mathrm{RS})$ had a significant effect compared to the single inoculation (CMA, RB and RS) and the control $(\mathrm{T})$. On the contrary, the difference observed with the native rhizobial strains (RB) and the arbuscular mycorrhizal fungus (CMA) was not significant compared to the control (T).

At 14 months after planting, the inoculation has induced a better development of the collar diameter for the inoculated plants compared to those not inoculated. This effect was more marked with the double inoculation $(\mathrm{CMA}+\mathrm{RB}$ and $\mathrm{CMA}+\mathrm{RS})$ compared to the single inoculation (CMA, RB and RS). With the single inoculation there was a significant difference between the rhizobial strain complexes (RB and RS) and the arbuscular mycorrhizal fungus.

About of the height, compared to the control, the inoculation stimulated growth in plant height. There was a significant difference between the double inoculation $(\mathrm{CMA}+\mathrm{RB}$ and $\mathrm{CMA}+\mathrm{RS})$ and the single inoculation (CMA, RB and RS).

\section{Field survival rate of plants}

All treatments improved the field survival rate of plants, when compared to the non-treated ones. In general, field survival rate (Table 5) was more significant in double inoculated plants than in single inoculated ones. 
Table 4: Effect of rhizobial strains inoculation on the growth of Vachellia seyal plants in greenhouse.

\begin{tabular}{|c|c|c|c|c|c|c|}
\hline \multirow{2}{*}{$\begin{array}{l}\text { Rhizobial } \\
\text { strain }\end{array}$} & \multicolumn{6}{|c|}{ Vachellia seyal growth parameter } \\
\hline & $\begin{array}{l}\text { Collar } \\
\text { diamete } \\
(\mathrm{mm})\end{array}$ & & Height (cm) & $\begin{array}{l}\text { Nodules } \\
\text { number }\end{array}$ & $\begin{array}{l}\text { Shoot } \\
\text { biomass } \\
\text { (mg) }\end{array}$ & $\begin{array}{ll}\text { Root biomass } \\
\text { (mg) }\end{array}$ \\
\hline AYJ1 & $\begin{array}{l}2.00 \\
0.55 \mathrm{a}\end{array}$ & \pm & $\begin{array}{l}10.31 \pm 2.06 \\
\text { ab }\end{array}$ & $11.7 \pm 5.72 \mathrm{~b}$ & $\begin{array}{l}174.3 \pm 60.97 \\
\mathrm{ab}\end{array}$ & $115.4 \pm 41.57 \mathrm{bcd}$ \\
\hline AYJ2 & $\begin{array}{l}2.20 \\
0.33 \mathrm{a}\end{array}$ & \pm & $\begin{array}{l}12.19 \pm 0.88 \\
\mathrm{a}\end{array}$ & $\begin{array}{l}20.6 \pm 13.66 \\
\text { ab }\end{array}$ & $\begin{array}{l}216.1 \pm \\
50.98 \mathrm{a}\end{array}$ & $152.6 \pm 36.03 \mathrm{abc}$ \\
\hline AYJ3 & $\begin{array}{l}2.08 \pm \\
0.30 \mathrm{a}\end{array}$ & & $\begin{array}{l}12.09 \pm 3.40 \\
\mathrm{ab}\end{array}$ & $16.1 \pm 9.12 \mathrm{ab}$ & $\begin{array}{l}215.1 \pm \\
62.17 \mathrm{a}\end{array}$ & $182.6 \pm 49.77 \mathrm{a}$ \\
\hline AYJ4 & $\begin{array}{l}2.06 \pm \\
0.47 \mathrm{a}\end{array}$ & & $\begin{array}{l}9.74 \pm 2.35 \\
a b\end{array}$ & $12.5 \pm 11.6 \mathrm{~b}$ & $\begin{array}{l}140.0 \pm \\
37.41 \mathrm{~b}\end{array}$ & $125.8 \pm 27.3 \mathrm{bc}$ \\
\hline AYJ5 & $\begin{array}{l}2.06 \pm \\
0.36 \mathrm{a}\end{array}$ & & $\begin{array}{ll}9.35 & \pm 2.01 \\
\mathrm{ab} & \end{array}$ & $27.3 \pm 13.86 \mathrm{a}$ & $\begin{array}{l}151.7 \pm \\
37.03 \mathrm{ab}\end{array}$ & $131.9 \pm 51.06 \mathrm{abc}$ \\
\hline AYJ6 & $\begin{array}{l}2.25 \\
0.31 \mathrm{a}\end{array}$ & \pm & $\begin{array}{l}10.15 \pm 1.14 \\
\text { ab }\end{array}$ & $\begin{array}{ll}19.6 \pm & 10.69 \\
a b & \end{array}$ & $\begin{array}{l}177.3 \pm \\
28.41 \mathrm{ab}\end{array}$ & $123.9 \pm 24.89 \mathrm{bc}$ \\
\hline AGJ1 & $\begin{array}{l}2.07 \\
0.43 \mathrm{a}\end{array}$ & \pm & $\begin{array}{l}10.29 \pm 1.64 \\
\text { ab }\end{array}$ & $12.3 \pm 5.77 \mathrm{~b}$ & $\begin{array}{l}175.6 \pm \\
38.83 \mathrm{ab}\end{array}$ & $151.7 \pm 36.53 \mathrm{abc}$ \\
\hline AGJ2 & $\begin{array}{l}2.07 \pm \\
0.39 \mathrm{a}\end{array}$ & & $\begin{array}{l}10.42 \pm 2.40 \\
a b\end{array}$ & $16.5 \pm 5.72 \mathrm{ab}$ & $\begin{array}{l}177.9 \pm \\
61.88 \mathrm{ab}\end{array}$ & $144 \pm 32.76 \mathrm{abc}$ \\
\hline AGJ3 & $\begin{array}{l}2.09 \\
\pm 0.17 \mathrm{a}\end{array}$ & & $\begin{array}{ll}9.78 & \pm 1.79 \\
a b & \end{array}$ & $12.5 \pm 7.92 \mathrm{~b}$ & $\begin{array}{l}164.3 \pm \\
45.08 \mathrm{ab}\end{array}$ & $128.2 \pm 23.99 b c$ \\
\hline AGJ4 & $\begin{array}{c}2.41 \\
0.41 \mathrm{a}\end{array}$ & \pm & $\begin{array}{ll}9.23 \pm & 1.54 \\
a b & \end{array}$ & $18.4 \pm 6.40 \mathrm{ab}$ & $\begin{array}{l}177.9 \pm \\
41.05 \mathrm{ab}\end{array}$ & $169.5 \pm 51.76 \mathrm{ab}$ \\
\hline AGJ5 & $\begin{array}{c}2.05 \\
0.21 \mathrm{a}\end{array}$ & \pm & $\begin{array}{l}11.12 \pm 2.04 \\
a b\end{array}$ & 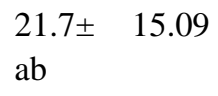 & $\begin{array}{l}167.5 \pm \\
41.16 \mathrm{ab}\end{array}$ & $136.5 \pm 33.29 \mathrm{abc}$ \\
\hline AGJ6 & $\begin{array}{c}2.25 \\
0.31 \mathrm{a}\end{array}$ & \pm & $\begin{array}{l}8.90 \pm 2.71 \\
a b\end{array}$ & $18.9 \pm 10.33 \mathrm{ab}$ & $\begin{array}{l}139.5 \pm \\
60.94 b\end{array}$ & $111.1 \pm 34.82 \mathrm{~cd}$ \\
\hline Control & $\begin{array}{l}1.52 \\
0.28 \mathrm{~b}\end{array}$ & \pm & $\begin{array}{l}7.80 \pm 3.69 \\
b\end{array}$ & 0.0 & $\begin{array}{l}117.4 \pm \\
57.31 \mathrm{~b}\end{array}$ & $75.8 \pm 40.42 d$ \\
\hline
\end{tabular}

In each column the values followed by the same letter are not significantly different according to the Newman Kheuls test (p $\leq 0.05)$. 


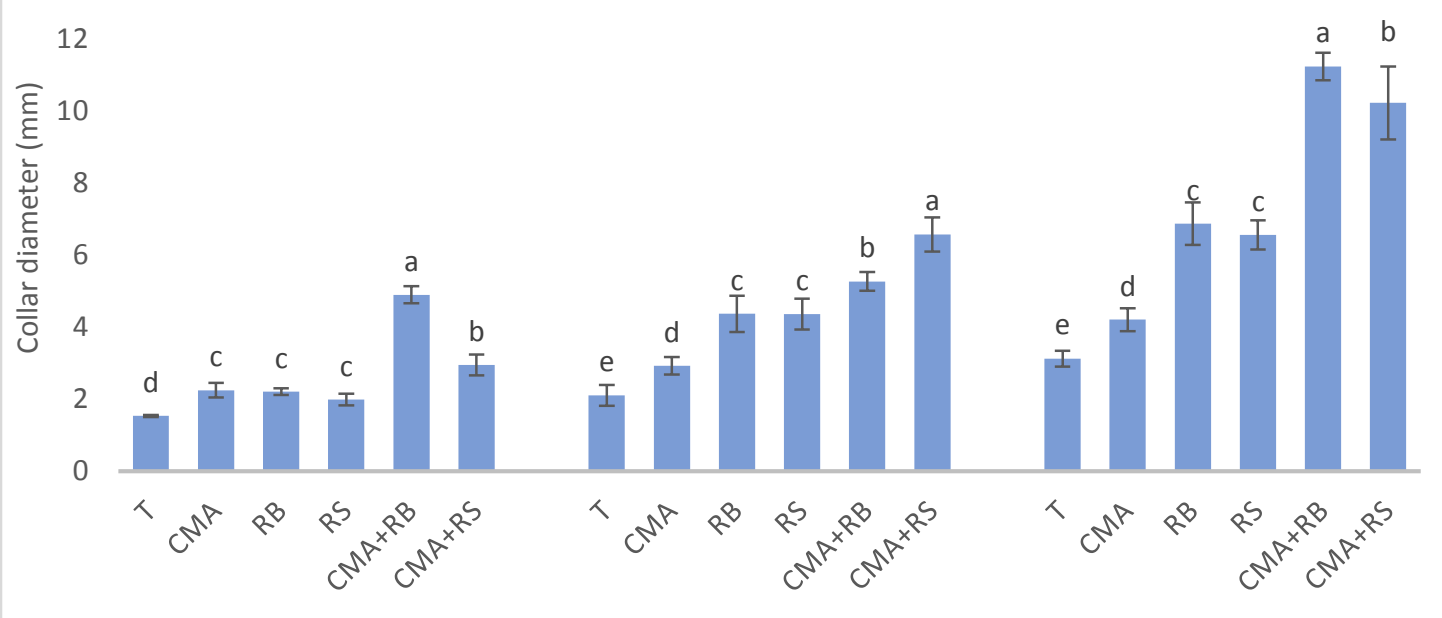

3 Months seeding

12 Months seeding

14 Months seeding

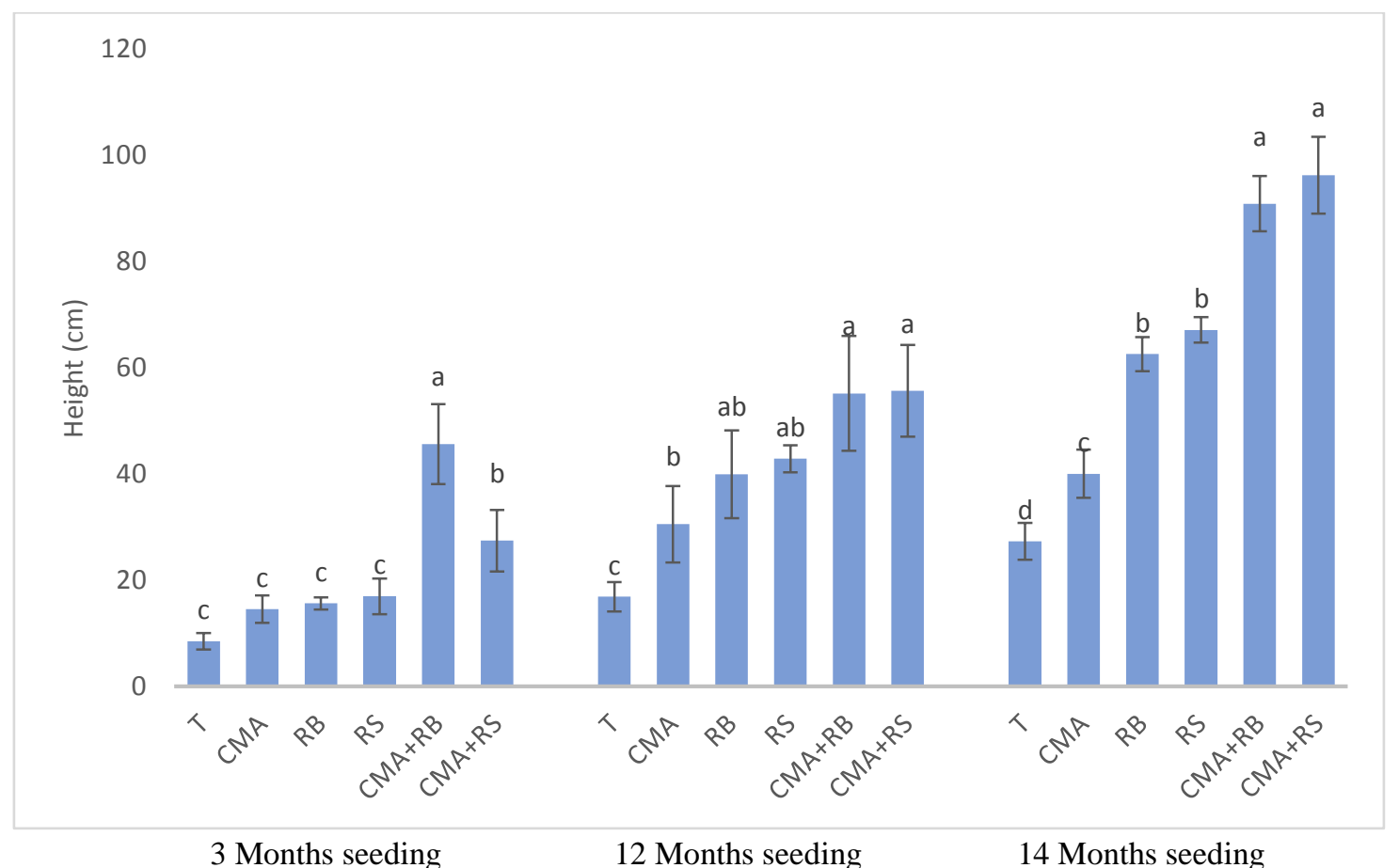

3 Months seeding

12 Months seeding

14 Months seeding

Figure 1: Effect of inoculation on the growth of Vachellia seyal direct seeding in field. 

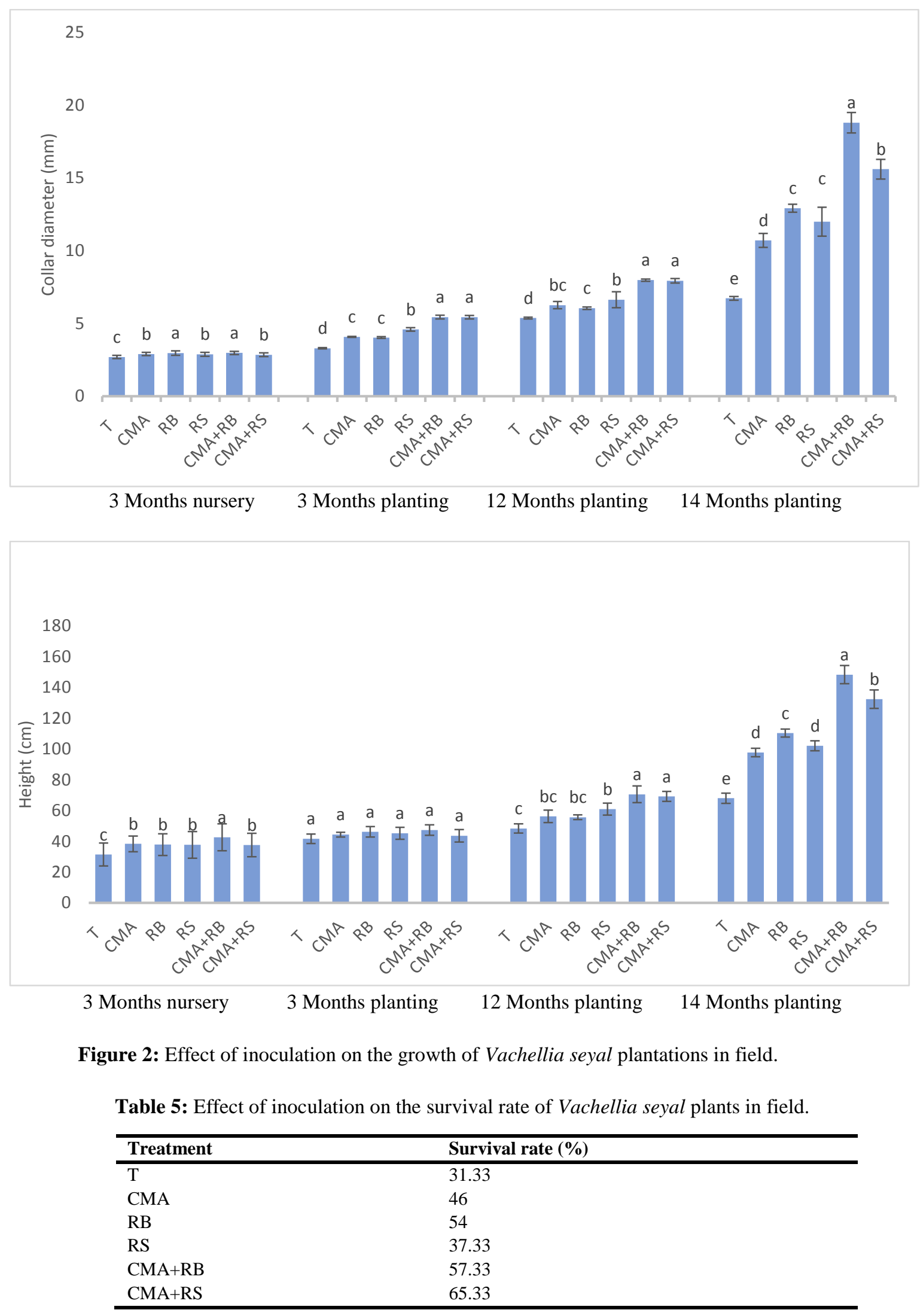


\section{DISCUSSION}

\section{The mycorrhization test}

The mycorrhization parameters observed were high. This indicated the compatibility between Vachellia seyal with the strain of Rizophagus irregularis used.

\section{Selection of efficient strains in greenhouse}

In our study, the number of nodules observed with the strains is relatively similar to that obtained by Backhoum et al. (2016) on Vachellia seyal inoculated with different strains of rhizobium. The production of nodules is an essential factor in the realization of a symbiotic relationship effective (N'Gbesso et al., 2017). Indeed, the nodulation stimulated the growth of plants by the fixation of nitrogen.

At the end of this experiment, three isolates (AYJ2, AYJ3 and AGJ4) were chosen to constitute the complex of native rhizobial strains inoculant due of their ability to improve the production of root biomass compared to others. In fact, plants produced in nursery that have a vigorous and strongly branched root system can bear the water stress they are confronted with after transplantation (Dianda et al., 2010).

\section{Field experimental test \\ Direct seeding}

The results show that inoculation has improved plant growth, showing the efficacy of the strains introduced in natural conditions. The positive effect of inoculation could be also explained by the fact that these microorganisms are adapted to the pedoclimatic conditions of the environment. In fact, some studies have shown that inoculation can only be effective when the microorganisms are adapted to the environment abiotic conditions (MeddadHamza et al., 2010). Our results contrast those of Diatta et al. (2013) who did not have a positive impact of inoculation on sesame in the natural environment due to presence of the native microflora. In our conditions of experiment where soil is degraded, there is absence of native microorganisms (Duponnois et al., 2001; Azcon-Aguilar et al., 2003) which could compete with the introduced ones.

The double inoculation has been more effective on the height growth and on the development of the collar diameter. This could be explained by the synergistical action between the arbuscular mycorrhizal fungi and the rhizobia, evidenced by some studies (Sene et al., 2010; Aboubacar et al., 2013). Thus with this treatments mineral and water nutrition increased as a result of better development of plants.

As per the single inoculation, the rhizobial complexes were more effective than the arbuscular mycorrhizal fungus. This could be due to the fact that the mycorhizae favorise plant growth in (i) a direct way by improving the mineral and water nutrition of the plants by the increase in the volume of soil prospected by the roots (mobilizing the nutrients in the deep horizons of the ground) and (ii) indirectly by improving the proliferation of other microorganisms that have the ability to solubilize minerals for the benefit of the plant (Requena et al., 2001; Barea et al., 2004). Under the conditions of our study, the soil being poor in microorganisms only the direct way of the arbuscular mycorrhizal fungus on the growth was performed. Furthermore, rhizobial complexes being more effective than the arbuscular mycorrhizal fungi could be related to the fact that in addition to fixing the atmospheric nitrogen, these strains of rhizobia are capable of phosphorus solubilization that can be assimilated by the plant (Peix et al., 2001).

\section{Plantation}

As with direct sowing, it was observed that inoculation induced a positive effect on the plants growth and that double inoculation being better than single inoculation. In addition, the field survival rate of plants was improved by the inoculation. Single inoculation with the arbuscular mycorrhizal fungus was found to be similar to that with rhizobial complexes. This could be explained 
by the fact that: (i) the cultivation substrate, used in nursery not being sterile, should contain symbiotic microorganisms (mycorrhizae and rhizobia) compatible with Vachellia seyal.

(ii) In addition, it also contained nonsymbiotic microorganisms (promoting growth plant rhizobacteria) involved in the major biogeochemical cycles of the $\mathrm{N}, \mathrm{P}$ and $\mathrm{C}$. These mechanisms allow a transformation of the chemical or organic elements into the nutrients dissolved in the soil solution that are then mobilizable by the plant to ensure its needs (Duponnois et al., 2013). So, the arbuscular mycorrhizal fungus will promote their proliferation and as a result the plant will benefit from their action. Indeed, it has been shown that the mycorhizal symbiotic exerts a selective pressure on the saprophytic microorganisms of the soil (Frey-Klett et al., 2005) in the goal of forming a trophic complex combining symbiote, mycorrhizospherical microflora and plant (Duponnois et al., 2017).

\section{Conclusion}

Our study showed that inoculation is beneficial to plant growth and the field survival of plants. The native rhizobial strains were efficient in natural conditions. The double inoculation was better than the simple inoculation. Transplanting plants produced better results than those issued from direct seeding. With these promising results, we recommend the wider use of inoculation of native microorganisms as a booster and benefit to the resilience and for a better success of restoration plantings in the dryland Sahel.

\section{COMPETING INTERESTS}

The authors declare that they have no competing interests.

\section{AUTHORS' CONTRIBUTIONS}

The authors, Barkissa FOFANA and Kadidia B. SANON, have conducted experiments in laboratory, in greenhouse and at the field.

All authors have designed and approved the manuscript.

\section{ACKNOWLEDGEMENTS}

This work was supported by the Action Against the Desertification (AAD) project implemented by the Food and Agriculture Organization (FAO) in support of the Great Green Wall program.

\section{REFERENCES}

Aboubacar K, Ousmane ZM, Amadou HI, Issaka S, Alzouma Mayaki Zoubeirou AM. 2013. Effet de la co-inoculation du rhizobium et de mycorhizes sur les performances agronomiques du niébé [Vigna unguiculata (L.) Walp.], Niger. Journal of Applied Biosciences, 72: 5846-5854.

DOI: https://doi.org/10.4314/jab.v72i1.99672

Amogu O. 2009. La dégradation des espaces sahéliens et ses conséquences sur l'alluvionnement $\mathrm{du}$ fleuve Niger: méthodes expérimentales et modélisation; Ph.D. Thesis ; Université Joseph Fourier: Grenoble, France, $440 \mathrm{p}$.

AUC/PA-GGW (African Union Commission/Panafrican Agency for the Great Green Wall). 2012. Harmonized regional strategy for the implementation of the Great Green Wall for the Sahara and the Sahel Initiative. Document developed with the technical and financial support of FAO, EU and the Global Mechanism of UNCCD. FAO : Rome, Italy.

Azcon-Aguilar C, Palenzuela J, Roldan A, Bautista S, Vallejo R, Barea JM. 2003. Analysis of the mycorrhizal potential in the rhizosphere of representative plant species from desertification-threatened Mediterranean shrublands. Applied Soil Ecology, 14: 165-175. DOI: https//doi.org/10.1016/S09291393(02)00107-5 
Bakhoum N, Odee WD, Fall D, Ndoye F, Kane A, Kimiti JM, Zoubeirou AM, Sylla SNd, Noba K, Diégane D. 2016. Senegalia Senegal response to inoculation with rhizobial strains vary in relation to seed provenance and soil type. Plant Soil, 398:181-193. DOI: https//dx.doi.org/ 10.1007/s11104-0152655-6

Bonkoungou EG. 2004. L'arbre à karité (Vitellaria paradoxa) et les parcs à karité en Afrique. In Atelier international sur le traitement, la valorisation et le commerce du karité en Afrique. FAO : Dakar, 54-63. da Silva IR, de Mello CMA, Neto RAF, da Silva DKA, de Melo AL, Oehl F, Maia, LC. 2014. Diversity of arbuscular mycorrhizal fungi along an environmental gradient in the Brazilian semiarid. Appl. Soil Ecol., 84 : 166-175. DOI : https: //dx.doi.org 10.1016/j.apsoil.2014.07.008.

Dianda M, Ouedraogo SJ, Diop TA. 2010. Variation de la réponse à l'endomycorhization en pépinière des plants issus de deux semenciers de karité au Burkina Faso. Int. J. Biol. Chem. Sci., 4(5): $\quad$ 1742-1752. DOI: https//doi.org/10.4314/ijbcs.v4i5.65560

Diatta M B, Laminou Manzo O, Macoumba Diouf P R, Diop T. 2013. Effets de l'inoculation mycorhizienne sur le sesame (Sesamum indicum L.) en conditions naturelles. Int. J. Biol. Chem. Sci., 7(5): 2050-2057 DOI: https://dx.doi.org/10.4314/ijbcs.v7i5.22

Duponnois R, Plenchette C, Thioulouse J., Cadet P., 2001. The mycorrhizal soil infectivity and arbuscular mycorrhizal fungal spore communities in soils of different aged fallows in Senegal. Applied Soil Ecology, 17: 239-251. DOI: https//dx.doi.org/10.1016/S09291393(01)00132-9

Duponnois R, Thioulouse J, Baudoin E, Le Roux C, Galiana A, Prin Y. 2017. Raisonner l'utilisation des légumineuses ligneuses pour réhabiliter des sols dégradés en milieu méditerranéen et tropical. Innovations Agronomiques, 60 : 125-131. DOI: https//dx.doi.org 10.15454/1.5138523036590977E12

FAO. 2016. Les changements climatiques, l'agriculture et la sécurité alimentaire. I5179F/1/01.16.

FAO-CILSS CSAO/OCDE. 2008. Climat, changements climatiques et pratiques agro-pastorales en zone sahélienne. Synthèse Régional.

Fortin JA, Plenchette C, Piché Y. 2008. Les Mycorhizes, la Nouvelle Révolution Verte. Éditions MultiMondes : Québec.

Frey-Klett P, Chavatte M, Clausse ML, Courrier S, Le Roux C, Raaijmakers J, Martinotti MG, Pierrat JC, Garbaye J. 2005. Ectomycorrhizal symbiosis affects functional diversity of rhizosphere fluorescent pseudomonads. New Phytologist, 165: 317-328. DOI: https//doi.org/10.1111/j.1469-8137.2004. 01212.x

Gibson AH. 1980. Methods for legumes in glasshouses and controlled environment cabinets. In Methods for Evaluating Biological Nitrogen Fixation ed. Bergersen, F.J. Chichester: WileyInterscience. 139-184.

Graham PH, Vance CP. 2003. Legumes: Importance and Constraints to Greater Use. Plant Physiology, 131:872-877. DOI : https://dx.doi.org/10.1104/pp.017004

Hien E, Kaboré WT, Masse D, Dugue P. 2012. Apports organiques et pratiques de conservation de l'eau comme clés de la restauration de la productivité des sols dégradés dans la zone semi-aride du Burkina Faso. IRD editions : Montpellier.

Karambiri H, Ribolzi O, Delhoume JP, Ducloux J, Coudrain-Ribstein A. 2003. Importance of soil surface characteristics on water erosion in a small grazed sahelian catchment. Hydrol. Process, 17: 1495-1507.

DOI: https//doi.org/10.1002/hyp.1195 
Lambers H, Raven JA, Shaver GR, Smith SE. 2008. Plant nutrient-acquisition strategies change with soil age. Trends in Ecology \& Evolution, 23: 95-103. DOI: https//doi.org/10.1016/j.tree.2007.10.008

Matiru VN, Dakora FD. 2004. Potential use of rhizobial bacteria as promoters of plant growth for increased yield in landraces of African cereal crops. African Journal of Biotechnology, 3: 1-7. DOI: https//dx.doi.org/10.5897/AJB2004.0002002

Meddad-Hamza A, Beddiar A, Gollotte A, Lemoine MC, Kuszala C, Gianinazzi S. 2010. Arbuscular mycorrhizal fungi improve the growth of olive trees and their resistance to transplantation stress. African Journal of Biotechnology, 9(8): 1159-1167.

DOI: https://dx.doi.org/10.5897/AJB09.1282

N'gbesso MFDP, Fondio L, Coulibaly ND, Kouame NC. 2017. Efficacité symbiotique de cinq souches locales de rhizobiums sur les paramètres de croissance du soja. Int. J. Biol. Chem. Sci., 11(5): 2327-2340. DOI: https://dx.doi.org/10.4314/ijbcs.v11i5.30

Ozer A, Ozer P. 2005. Désertification au Sahel : crise climatique ou anthropique? Bull. Séanc. Acad. R. Sci. Outre-Mer Meded. Zitt. K. Acad. Overzeese Wet., 51: 395-423.

Peix A, Rivas-Boyero AA, Mateos PF, Rodriguez-Barrueco C, Martinez-Molina E, Velazquez E. 2001. Growth promotion of chickpea and barley by a phosphate solubilizing strain of Mesorhizobium mediterraneum under growth chamber conditions. Soil Biol Biochem, 33: 103-110. DOI: https://dx.doi.org/10.1016/S00380717(00)00120-6

Räsänen AL. 2002. Biotic and abiotic factors influencing the development of $\mathrm{N}_{2}$-fixing symbioses between rhizobia and the woody legumes Acacia and Prosopis. Academic dissertation in microbiology: Helsinki
Requena N, Perez-Solis E, Azcón-Aguilar C, Jeffries P, Barea JM. 2001. Management of Indigenous Plant-Microbe Symbioses Aids Restoration of Desertified Ecosystems. Applied and Environmental Microbiology, 67(2): 495-498. DOI: www//https:/dx.doi.org/10.1128/AEM.6 7

Requier-Desjardins M, Caron P. 2005. La lutte contre la désertification: Un bien public mondial environnemental ? Des éléments de réponse...Les dossiers thématiques du CSFD numéro 1 . Agropolis productions : Montpellier.

Roose E, Zougmore R, Stroosnijder L, Dugué P, Bouzou-moussa I. 2017. Techniques traditionnelles de restauration de la productivité des sols dégradés en régions semi-arides d'Afrique occidentale. In Restauration de la Productivité des Sols Tropicaux et Méditerranéens, Contribution à l'Agroécologie. IRD Edition: Montpellier; 491-517.

Sacande M, Berrahmouni N. 2018. Africa's Great Green Wall: A transformative model for rural communities' sustainable development In Enhancing Natural Resources Management for Food Security in Africa. Nature \& Faune. FAO: Accra; 32: 90-99.

Sacande M, Berrahmouni N. 2016. Community participation and ecological criteria for selecting species and restoring natural capital with native species in the Sahel. Restoration Ecology, 24: 479-488. DOI: https://dx.doi.org/10.1111/rec.12337

Sacande M, Sanou L, Beentje H. 2012. Guide d'Identification des Arbres du Burkina Faso. Kew Publishing: London.

Safriel U, Adeel Z, Niemeijer D, Puigdefabregas J, White R, Lal R, Winslow M, Ziedler J, Prince S, Archer E, King C, Shapiro B, Wessels K, Nielsen TT, Portnov B, Reshef I, Thornell J, Lachman E, McNab D. 2005. Ecosystems and Human Well-Being: Current State and Trends: Findings of 
the Condition and Trends Working Group (vol.1). Island Press; 623-662.

Sene G, Thiao M, Samba Mbaye R, Ndoye F, Kane A, Diouf D, Sylla SN. 2010. Response of three peanut cultivars toward inoculation with two Bradyrhizobium strains and an arbuscular mycorrhizal fungus in Senegal. African Journal of Microbiology Research, 4(21): 25202527.

DOI: https://dx.doi.org/10.5897/AJMR-

A7FB6C415875

Temegne NC, Nkou Foh TD, Taffouo VD, Ntsomboh-Ntsefong G, Youmbi E. 2017. Influence of mycorrhization and phosphate fertilizer on growth of Voandzou (Vigna subterranea (L.) Verdc.) Int. J. Biol. Chem. Sci., 11(6): 2587-2593.

DOI: https://dx.doi.org/10.4314/ijbcs.v11i6.3
Trouvelot A, Kouch J, Gianinazzi-Pearson V. 1986. Mesure du taux de mycorhization VA d'un système radiculaire: Recherche de méthodes d'estimation ayant une signification fonctionnelle. In Aspects Physiologiques et Génétiques des Mycorhizes. INRA: Dijon, France ; $217-$ 221.

Vincent JM. 1970. A manual for the Practical Study of Root-Nodule Bacteria. International Biological Programme. Blackwell, Handbook $\mathrm{n}^{\circ}$ 15: Oxford, Royaume-Uni.

Weaver RW, Frederick LR. 1982. Rhizobium. In Methods of Soil Analysis, Part 2. Chemical and Microbiolgical PropertiesAgronomy Monogrash $\mathrm{n}^{\circ}$, ed. Segoe Rd. : Madison, USA. 